\title{
Measurements in a highly polluted Asian mega city: observations of aerosol number size distribution, modal parameters and nucleation events
}

\author{
P. Mönkkönen ${ }^{1}$, I. K. Koponen ${ }^{1}$, K. E. J. Lehtinen ${ }^{1}$, K. Hämeri ${ }^{1,2}$, R. Uma ${ }^{3}$, and M. Kulmala ${ }^{1}$ \\ ${ }^{1}$ University of Helsinki, Department of Physical Sciences, Finland \\ ${ }^{2}$ Finnish Institute of Occupational Health, Helsinki, Finland \\ ${ }^{3}$ The Energy and Resources Institute (TERI), New Delhi, India
}

Received: 3 June 2004 - Published in Atmos. Chem. Phys. Discuss.: 17 September 2004

Revised: 1 December 2004 - Accepted: 3 January 2005 - Published: 19 January 2005

\begin{abstract}
Diurnal variation of number size distribution (particle size 3-800 nm) and modal parameters (geometric standard deviation, geometric mean diameter and modal aerosol particle concentration) in a highly polluted urban environment was investigated during October and November 2002 in New Delhi, India. Continuous monitoring for more than two weeks with the time resolution of $10 \mathrm{~min}$ was conducted using a Differential Mobility Particle Sizer (twin DMPS). The results indicated clear increase in Aitken mode (25-100 nm) particles during traffic peak hours, but towards the evenings there were more Aitken mode particles compared to the mornings. Also high concentrations of accumulation mode particles $(>100 \mathrm{~nm})$ were detected in the evenings only. In the evenings, biomass/refuse burning and cooking are possible sources beside the traffic. We have also shown that nucleation events are possible in this kind of atmosphere even though as clear nucleation events as observed in rural sites could not be detected. The formation rate of $3 \mathrm{~nm}$ particles (J3) of the observed events varied from 3.3 to $13.9 \mathrm{~cm}^{-3} \mathrm{~s}^{-1}$ and the growth rate varied from 11.6 to $18.1 \mathrm{nmh}^{-1}$ showing rapid growth and high formation rate, which seems to be typical in urban areas.
\end{abstract}

\section{Introduction}

Numerous aerosol number size distribution and number concentration measurements has been conducted in urban environments in developed countries like United States, United Kingdom, Germany and Finland (Hämeri et al., 1996; Williams et al., 1998; Shi et al., 2001; Woo et al., 2001; Wehner et al., 2002; Longley et al., 2003). The studies that have examined number size distribution or number con-

Correspondence to: P. Mönkkönen

(petteri.monkkonen@helsinki.fi) centration of aerosols in Asia, Latin America or Africa are very few (Baumgardner et al., 2000; Jayaratne and Verma, 2001; Mitra and Sharma, 2002; Mönkkönen et al., 2004a; Mönkkönen et al., 2004b; Mönkkönen et al., 2005) even though the air pollution problem is particularly serious in the mega cities of South and East Asia. Especially the cities like Delhi, Kolkata (Calcutta), Mumbai (Bombay), Dhaka, Karachi, Bangkok, Beijing, Shanghai, Jakarta, and Manila are concerned to be one of the most polluted cities (Balsano et al., 2003; Faiz and Sturm, 2000). In India, most of the aerosol number size distribution measurements have been carried on Indian Ocean and Arabian Sea (de Reus et al., 2001; Kamra et al., 2003; Krishnamoorthy et al., 2000; Krishnamoorthy et al., 1997) and only short experiments at inland and coastal stations have been performed (Murugavel and Kamra, 1999; Rao et al., 1999).

The major source of particulate matter (PM) and air pollution in the South and East Asia region is due to rapid urbanization and increasing vehicle density (Faiz and Sturm, 2000). For example the vehicular population in New Delhi has increased from 235000 from 1975 to 2629000 in 1996. An estimate as high as 6000000 vehicles in year 2011 has been proposed by Ministry of Environment and Forest of India (Goyal and Krishna, 1998).

Traffic has been observed to be one major primary source of nucleation mode $\left(D_{p}<25 \mathrm{~nm}\right)$ particles (Longley et al., 2003; Shi et al., 2001) and it is also the major source of ultrafine particles in New Delhi (Mitra and Sharma, 2002). One solution for decreasing air pollution in New Delhi has been applying Compressed Natural Gas (CNG) engine technology. We might speculate that applying CNG technology to transportation will not bring solution for the level of fine and ultrafine particles, since CNG and diesel engines have been found to be the major source of fine $\left(D_{p}<1000 \mathrm{~nm}\right)$ and ultrafine $\left(D_{p}<100 \mathrm{~nm}\right)$ particles (Ristovski et al., 2000; Ristovski et al., 1998; Kittelson, 1998).

(C) 2005 Author(s). This work is licensed under a Creative Commons License. 


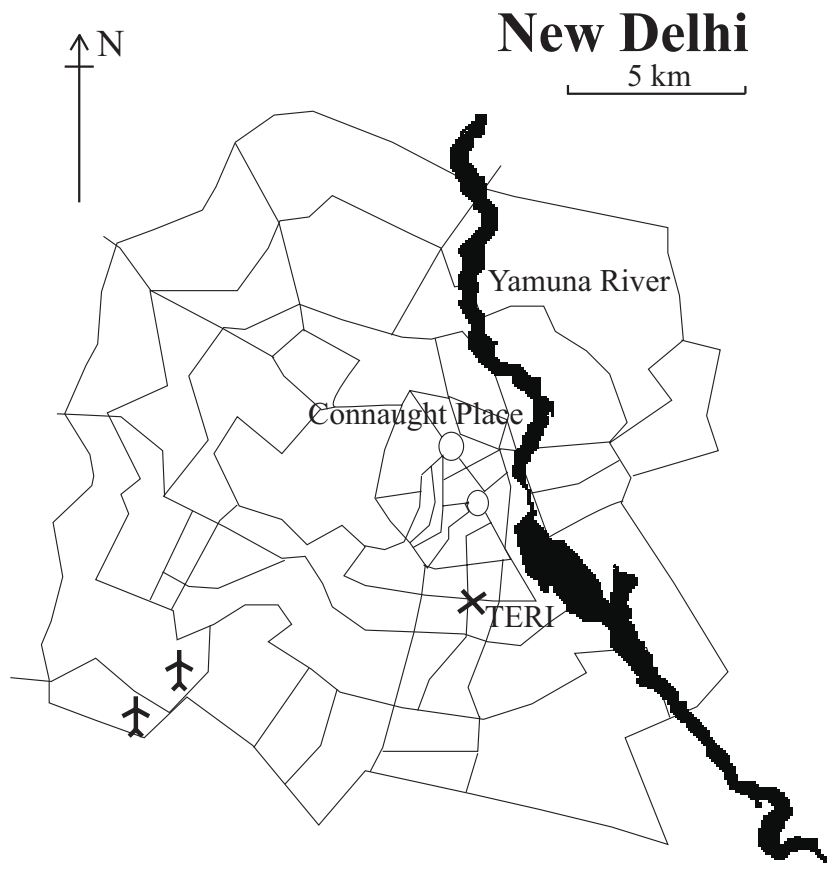

Fig. 1. The location of the sampling site in New Delhi.

In India, atmospheric aerosols are also emitted from combustion of fossil fuels (e.g. coal and liquefied petroleum gas (LPG) and biofuel (e.g. wood, dung-cake, crop waste) both in industrial and domestic sector. Emissions from fossil fuel combustion are localized to large point sources (utilities, refineries and petrochemicals, cement and fertilizers) and major cities while emissions from biofuel combustion are area sources spread all over India (Reddy and Venkataraman, 2002a; Reddy and Venkataraman, 2002b).

The formation of new particles has been observed at a number of sites around the world. However, there are much less experiments performed in urban than rural locations (Kulmala et al., 2004b). One reason for this might be that the formation of new particles in the urban atmosphere is expected to be far less favoured than in the rural atmosphere due to the high existing surface area for condensation of nonvolatile materials needed for homogeneous nucleation. Even though the identification of new particle formation is more difficult due to the large background particle concentrations (Alam et al., 2003), nucleation events have been observed polluted environments like Mexico City (Dunn et al., 2004). New particle formations in urban environments has also been observed Atlanta (Woo et al., 2001), Birmingham, UK (Alam et al., 2003), St Louis (Shi et al., 2002), and Pittsburg (Stainer et al., 2002).

The main objective of this study is to determine the diurnal variation of number size distribution $(3-800 \mathrm{~nm})$, the total number concentration and the modal parameters of urban background aerosols. The formation of nucleation mode particles in highly polluted Asian mega city is studied for the first time.

\section{Methods}

The field experiment was performed at India Habitat Centre (IHC/TERI) in New Delhi from 26 October to 9 November 2002. The measuring site located next to a traffic line in a residential area at the altitude of $15 \mathrm{~m}$. Other similar type of office building located right to IHC building, but there were only small individual private houses locating opposite of the IHC building. The location of the site is shown in Fig. 1.

Aerosol number size distributions were measured over the size range 3-800 nm using a twin differential mobility particle sizer (DMPS). The twin DMPS system consists of two Vienna-type DMAs (lengths 11 and $28 \mathrm{~cm}$; see Winklmayr et al., 1991), two CPCs, TSI 3025 (Stolzenburg and McMurry, 1991) and TSI 3010 (Quant et al., 1992). The DMAs were used for the electrical mobility diameter size classification of the particles and CPCs measured the total particle number concentration after the classification. The sheath air volume flow rates of the DMA's were equal to 5.4 and $17.5 \mathrm{~L} / \mathrm{min}$ covering the subranges $3-10 \mathrm{~nm}$ and $10-800 \mathrm{~nm}$. The time resolution for the whole size range was $10 \mathrm{~min}$. The sheath flows of DMAs were maintained using a closed sheath-air loop using critical orifices (Jokinen and Mäkelä, 1997). The relative humidities of the sheath flows were kept below $25 \%$ with dryers.

The DMPS system was placed in the fifth floor next to a window. The inlet tube was placed outside of the window so that the inlet was $15 \mathrm{~m}$ above the ground level and $0.5 \mathrm{~m}$ from the wall of the building.

The sample air was led through a vertically-placed, $60-\mathrm{mm}$ steel tube with a total flow of $26.5 \mathrm{~L} / \mathrm{min}$. The sample was taken from the main flow and led to instruments trough a 30$\mathrm{cm}$-long stainless steel tube having a diameter of $6 \mathrm{~mm}$. All the CPC's and DMA's were calibrated before the campaign. The calibration method has been described in detail by Aalto et al. (2001).

We used the same data inversion and fitting procedure in our investigation as Mäkelä et al. (2000a) in their analysis of typical continental air masses in Southern Finland. In our analysis we also describe the aerosol size distribution by a few well chosen parameters. These parameters are the geometric mean diameter (GMD), the geometrical standard deviation $(\sigma)$ and the modal aerosol particle concentration $(\mathrm{N})$.

The weather conditions were stable during whole experiment. Days were sunny, but hazy, and no rain was observed. Diurnal maximum and minimum temperature and relative humidity is presented in the Table 1 . The effect of a long range transport to New Delhi's climate from other polluted regions was studied with help of NOAA HYSPIT trajectory Model. The analysis of the trajectories indicated low impact of other air masses to New Delhi's climate during the measuring period. 
Table 1. Diurnal maximum and minimum temperature and relative humidity during the measuring period.

\begin{tabular}{cccccc}
\hline Date & Day of year & $T_{\max }\left({ }^{\circ} \mathrm{C}\right)$ & $T_{\min }\left({ }^{\circ} \mathrm{C}\right)$ & $R H_{\max }(\%)$ & $R H_{\min }(\%)$ \\
\hline 26 Oct & 299 & 32 & 17 & 80 & 35 \\
27 Oct & 300 & 32 & 17 & 86 & 35 \\
28 Oct & 301 & 32 & 16 & 90 & 35 \\
29 Oct & 302 & 33 & 16 & 92 & 39 \\
30 Oct & 303 & 32 & 19 & 88 & 41 \\
31 Oct & 304 & 32 & 18 & 89 & 41 \\
1 Nov & 305 & 31 & 17 & 92 & 39 \\
2 Nov & 306 & 31 & 16 & 91 & 36 \\
3 Nov & 307 & 32 & 16 & 86 & 34 \\
4 Nov & 308 & - & - & - & - \\
5 Nov & 309 & 30 & 15 & - & - \\
6 Nov & 310 & 29 & 16 & 90 & 42 \\
7 Nov & 311 & 29 & 16 & 92 & 47 \\
8 Nov & 312 & 28 & 15 & 93 & 47 \\
9 Nov & 313 & - & - & - & - \\
\hline
\end{tabular}

\section{Results and discussion}

3.1 Diurnal variations of the number size distribution and the number concentration

Figures 2 and 3 presents the measured particle size distribution (Figs. 2a and 3a) and the number concentration (Figs. 2b and 3b) from 28 October to 1 November 2002 (Fig. 2) and from 4 November to 8 November 2002. (Fig. 3). These selected days present typical variations both in particle size distribution and number concentration of New Delhi's climate during the measuring period. The substantial pollution event observed 4-5 November (Day of Year 308-309) is reported by Mönkkönen et al. (2004b). The number size distribution changed and the number concentration increased during the morning traffic peak hour (7-9 a.m.) and again in the evenings $(6-10$ p.m.). After the morning peak hour the number concentration decreased rapidly. This phenomenon can be explained by mixing within the developing boundary layer. Similar changes in the aerosol particle number concentrations were obtained also during different seasons (Mönkkönen et al., 2004a). It is evident that the evening peak hour was also influenced by the traffic, but as we can see from Fig. 2a, the number size distribution differs between the morning and the evening. Especially during 28, 30 and 31 October (\#301, 303 and 304, respectively) we clearly are able to see that there were less Aitken mode $(25-100 \mathrm{~nm})$ particles at morning compared to the evening. From Figs. 2 and 3 we are also able to see a large background aerosol population in New Delhi. During the measuring period the aerosol number concentration varied between 20000 (4 Nov., \#308, 3 p.m.) to 250000 particles $\mathrm{cm}^{-3}$ (6 Nov., \#310, 8 a.m.). A highest measured 24-h average was $(6.28 \pm 1.78) \times 10^{4} \mathrm{~cm}^{-3}$. This average was more than two times higher compared to results measured by Shi et al. (1999) at roadside in UK and almost five times higher compared to average measured in three communities in East Germany between 1993 and 1999 (Pitz et al., 2001).

Figure 4 presents selected diurnal number size distributions ( $1 \mathrm{~h}$ mean) on 28 October 2002. Figure 4 a presents the size distributions before noon and Fig. $4 \mathrm{~b}$ after noon. From Fig. 4a we can clearly see the increase in Aitken mode particles during traffic peaks hours (7-9 a.m. and 4-5 p.m.). During this day the concentration of Aitken mode particles remained almost the same level even between 10-11 a.m. After this point, the concentration of Aitken mode particles decreased until the concentration increased again after 4 p.m. Towards the evening the geometric mean diameter (GMD) of the particles increased so that at 10-11 p.m. there were a lot of accumulation mode $\left(D_{p}>100 \mathrm{~nm}\right)$ particles in the atmosphere. The increase of GMD and number concentration of the particles towards the evening in discussed in the next chapter. During the whole measuring period, high concentrations of accumulation mode particles were detected in the evenings and after midnight only. The decrease of accumulation mode particles after midnight could be explained by gravitational settling. Also in the evenings there were more Aitken mode particles compared to the mornings. Hence, there must be also another source at evenings, which beside the traffic, which is frequently repeated every day.

\subsection{Diurnal variations of modal parameters}

Table 2 summarizes the calculated arithmetic mean $(30 \mathrm{~min})$ and Figs. 5a-c present the calculated geometric mean ( $30 \mathrm{~min}$ ) of the diurnal variations of modal parameters for each mode obtained from the fitting procedure. The mean values are calculated from the whole measuring period. 

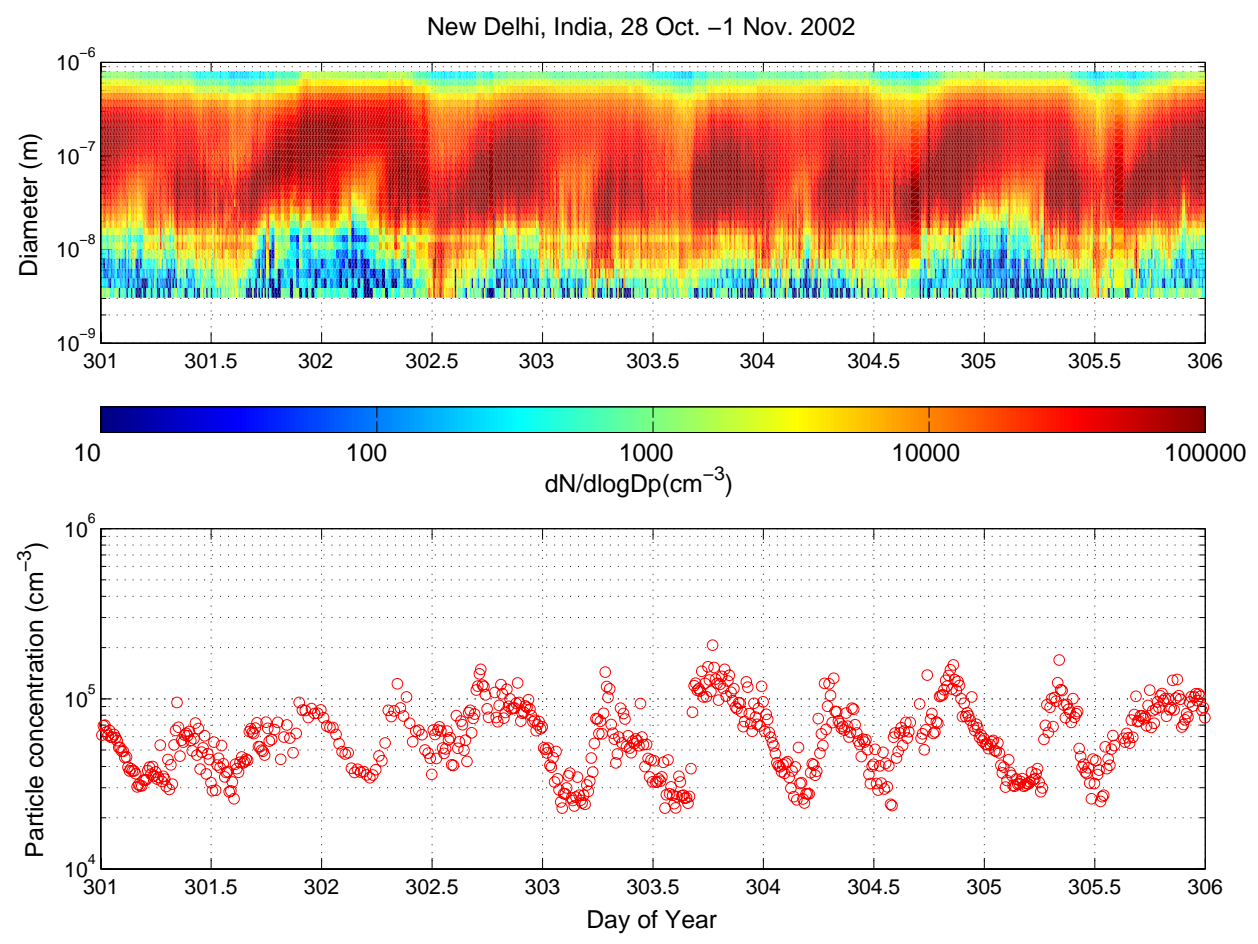

Fig. 2. Measured aerosol number size distribution (Fig. 2a) and number concentration (Fig. 2b) from 28 October to 1 November 2002 . The $\mathrm{x}$-axis represents the time and $\mathrm{y}$-axis in the Fig. 2a particle diameter $(\mathrm{m})$ and in Fig. $2 \mathrm{~b}$ particle concentration $\left(\mathrm{cm}^{-3}\right)$ for the same period. The color in the Fig. 2 a represents particle concentration $\left(d N / d \log D_{p}\right)$.
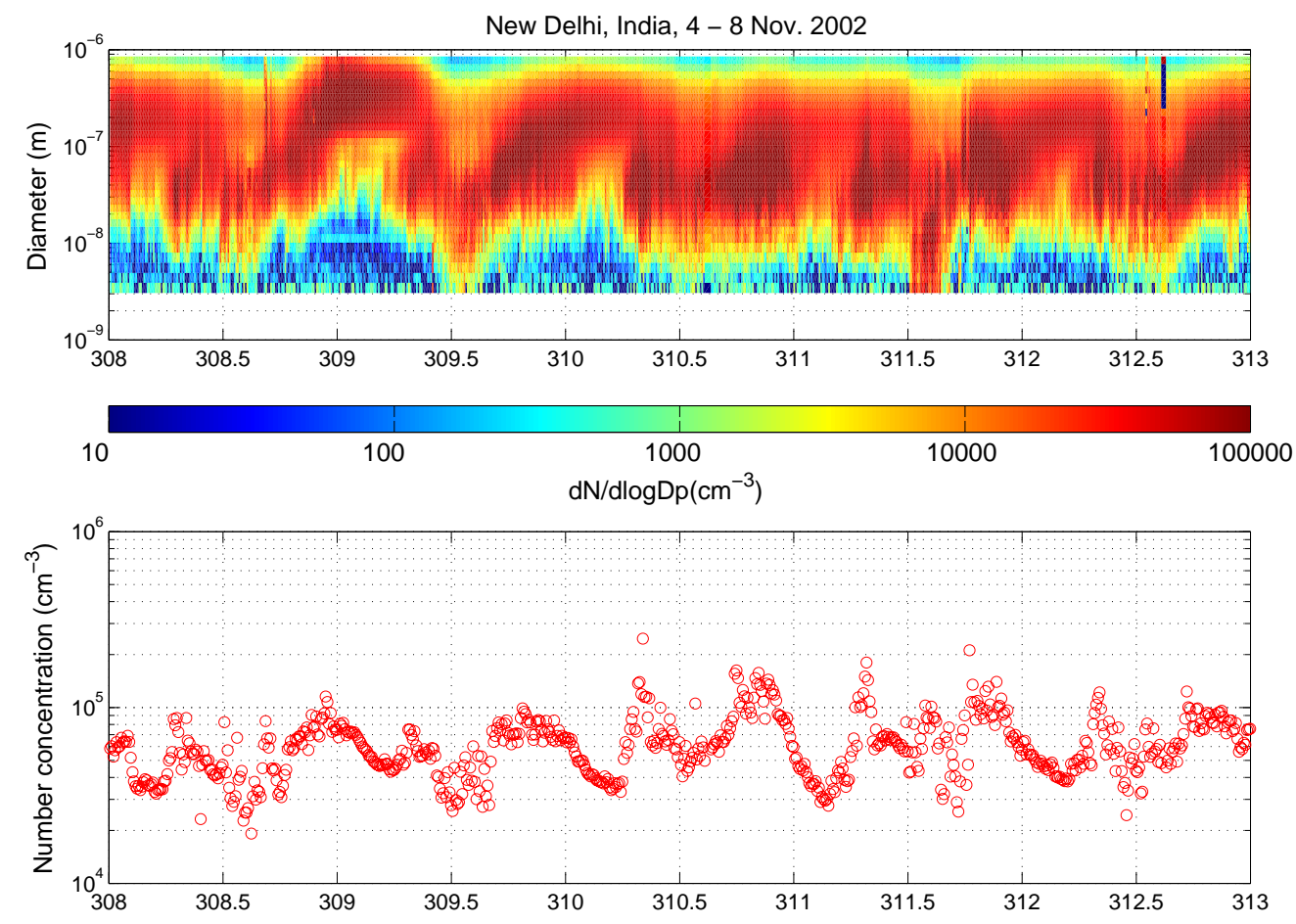

Fig. 3. Measured aerosol number size distribution (Fig. 3a) and number concentration (Fig. 3b) from 4 to 8 November 2002. 
Table 2. Diurnal arithmetic averages of the nine size distribution parameters during the measuring campaign obtained from the fitting procedure. The standard deviation of each quantity is given is parentheses.

\begin{tabular}{|c|c|c|c|c|c|c|c|c|c|c|c|c|c|c|c|c|c|c|}
\hline \multirow{3}{*}{$\begin{array}{c}\text { Time of day } \\
0.0128\end{array}$} & \multicolumn{6}{|c|}{ Nucleation mode } & \multicolumn{6}{|c|}{ Aitken mode } & \multicolumn{6}{|c|}{ Accumulation mode } \\
\hline & \multicolumn{2}{|c|}{ GMD (nm) } & \multicolumn{2}{|c|}{$N_{\text {tot }}\left(\mathrm{cm}^{-3}\right)$} & \multicolumn{2}{|c|}{$\sigma$} & \multicolumn{2}{|c|}{ GMD (nm) } & \multicolumn{2}{|c|}{$N_{t o t}\left(\mathrm{~cm}^{-3}\right)$} & \multicolumn{2}{|c|}{$\sigma$} & \multicolumn{2}{|c|}{ GMD (nm) } & \multicolumn{2}{|c|}{$N_{\text {tot }}\left(\mathrm{cm}^{-3}\right)$} & \multicolumn{2}{|c|}{$\sigma$} \\
\hline & 9,7 & $(1,8)$ & 587 & (1130) & 0.4 & $(0.6)$ & 43.7 & (7.5) & 19924 & (9766) & 1.6 & $(0.2)$ & 138.0 & $(16.2)$ & 41762 & (10278) & 1.8 & 1) \\
\hline 0.0544 & 12,4 & $(5,0)$ & 736 & (2091) & 0.7 & (1.3) & 50.2 & $(12.1)$ & 16978 & $(5903)$ & 1.8 & $(0.2)$ & 150.7 & & 35210 & (9491) & 1.7 & $0.1)$ \\
\hline 0.0751 & 7,2 & $(3,9)$ & 254 & & 0.4 & $(1.1)$ & 52.2 & $(13.5)$ & 15515 & & 1.9 & & & & 1782 & 425) & 1.7 & $(0.2)$ \\
\hline 0.0958 & 9,2 & $(2,3)$ & 95 & (319) & 0.2 & $(0.4)$ & 55.2 & (17.0) & 14537 & & 1.9 & $(0.3)$ & 161.9 & & 5 & & 1.7 & $(0.1)$ \\
\hline 0.1585 & 9,7 & $(2,3)$ & 690 & (2167) & 0.3 & $(0.7)$ & 46.0 & $(16.2)$ & 8264 & & 1.9 & $(0.5)$ & & & & & 1.7 & $(0.1)$ \\
\hline 0.1794 & 14,0 & $(6,9)$ & 442 & (1246) & 0.3 & $(0.7)$ & 47.2 & $(16$ & & $(4275)$ & 1.9 & $(0.4)$ & 161.8 & $(17.5)$ & 26443 & & 1.7 & \\
\hline 0.2004 & 14,8 & $(10,0)$ & 308 & (870) & 0.2 & $(0.6)$ & 48.3 & $(16.9)$ & 9874 & $(5458)$ & 2.0 & $(0.3)$ & 163.7 & $(20.3)$ & 25471 & & 1.7 & $(0.1)$ \\
\hline 0.2212 & 7,8 & $(2,2)$ & 969 & (2193) & 0.3 & $(0.6)$ & 36.9 & $(10.0)$ & 12714 & (72 & .8 & & 160.6 & 20.0) & 1 & & 1.8 & $(0.2)$ \\
\hline 0.2416 & 8,8 & $(1,1)$ & 1756 & (4744) & 0.3 & (0.6) & 34.9 & & 17431 & & 1.7 & & & & & & 1.8 & $(0.2)$ \\
\hline 0.2629 & 8,6 & $(0,5)$ & 1181 & & 0.4 & $(0.6)$ & & & & & 1.7 & & & & & & 1.8 & $(0.2)$ \\
\hline 0.3669 & 12,4 & $(4,8)$ & 1320 & (16 & 1.0 & (1.1) & & & & & 1.7 & $(0.1)$ & 14 & & 1 & & 1.9 & $(0.2)$ \\
\hline 0.3878 & 12,7 & $(3,4$ & 114 & $(15$ & 1.0 & (1. & 41 & (7. & 380 & & 1.7 & $(0$. & 137 & & 7941 & & .9 & $(0.2)$ \\
\hline 0.4086 & 9 & $(3,0$ & 163 & $(229$ & 0.9 & & 40 & & 329 & & 1.7 & & & ( & & & .9 & $(0.3)$ \\
\hline 95 & 10,0 & $(3,5$ & 13 & (14 & 1.2 & & 39.1 & & 32 & & 1.7 & $(0$ & 130.7 & & 25 & & 1.9 & $(0.2)$ \\
\hline 0.4501 & 10,2 & $(3,2)$ & 1821 & (19 & 1.2 & (0.9) & 39.7 & (4. & 28021 & & 1.7 & $(0.1)$ & 135.8 & (22) & 20760 & & 1.9 & $(0.2)$ \\
\hline 0.4709 & 10,2 & $(3,3)$ & 1823 & (23 & 1.2 & $(0.9)$ & 38.3 & (7.1) & & & 1.7 & $(0.1)$ & & & & & 1.9 & $(0.3)$ \\
\hline 0.4912 & 9,3 & $(2,3)$ & 1839 & (14. & 1.4 & $(0.8)$ & 35 & (6.1) & 23793 & & 1.7 & $(0.1)$ & & $(29.8)$ & 17662 & & 1.9 & $(0.2)$ \\
\hline 0.5130 & 9,7 & $(3,5)$ & 4191 & $(4720)$ & 1.5 & $(0.5)$ & 35.3 & (5. & 23194 & (93 & 1.7 & $(0.2)$ & 139.9 & $(27.6)$ & 145 & & 1.8 & $(0.2)$ \\
\hline 0.5337 & 8,2 & $(2,8)$ & 4254 & $(6378)$ & 1.3 & $(0.7)$ & 33.6 & (6.7) & 27622 & (12522) & 1.7 & $(0.3)$ & 145.2 & $(27.0)$ & 13351 & (6) & 1.8 & $(0.3)$ \\
\hline 0.5545 & 8,5 & $(4,8)$ & 3004 & & 1.4 & & & & & & 1.8 & & & & & & .7 & $(0.2)$ \\
\hline 0.5748 & 8 & $(4,2$ & 7145 & (158 & 1.4 & & & & & & 1.6 & & & & & & .8 & $(0.2)$ \\
\hline 0.5952 & 9 & $(2,5$ & 7908 & (179 & 1. & $(0$ & 35 & (7. & 281 & & 1.6 & & 14 & $(29.7)$ & 107 & & .8 & $(0.2)$ \\
\hline 0.61 & 9,8 & $(2,9$ & 6028 & $(140$ & 1.6 & $(0$. & 36.7 & (9. & 30010 & & 1.7 & $(0$ & 14 & $(25$ & 10211 & & 1.8 & $(0.2)$ \\
\hline 0.8043 & 13,1 & $(10,2)$ & 363 & (926) & 0.3 & $(0.6)$ & 58.1 & (11.3) & 61064 & (239 & 1.7 & (0.1) & 144.4 & $(34.8)$ & 28379 & (19 & 1.7 & $(0.2)$ \\
\hline 0.8251 & 20,0 & $(11,1)$ & 662 & (2004) & 0.4 & $(0.7)$ & 60.5 & (13.8) & 55963 & (26333) & 1.8 & $(0.2)$ & 135.5 & (36.6) & 32127 & (21381) & 1.7 & $(0.2)$ \\
\hline 0.8459 & 22,8 & $(13,4)$ & 863 & (2477) & 0.3 & $(0.6)$ & 58.9 & (14.8) & 61053 & (33866) & 1.8 & $(0.2)$ & 128.8 & $(26.9)$ & 36038 & $(23082)$ & 1.7 & $(0.2)$ \\
\hline 0.8661 & 19,5 & $(2,5)$ & 436 & (1892) & 0.1 & $(0.4)$ & 57.8 & (13.5) & 54456 & (32384) & 1.9 & $(0.3)$ & 129.2 & $(18.0)$ & 36818 & $(21814)$ & 1.7 & $(0.2)$ \\
\hline 0.8878 & 19,7 & $(6,5)$ & 339 & (1639) & 0.3 & $(1.2)$ & 54.3 & $(15.8)$ & 48003 & (32529) & 1.8 & $(0.2)$ & 123.3 & $(20.1)$ & 41539 & $(21550)$ & 1.7 & $(0.3)$ \\
\hline 0.9087 & 9,1 & $(0,4)$ & 154 & & 0.1 & $(0.3)$ & 48.0 & (13.6) & 31942 & (24434) & 1.7 & $(0.3)$ & 117.6 & $(26.8)$ & 48162 & (17210) & 1.8 & $(0.2)$ \\
\hline 0.9294 & 14,5 & $(3,9)$ & 274 & & 0.1 & $(0.3)$ & 49.3 & & & & 1.7 & $(0.2)$ & 130.8 & (18.7) & 45551 & & 1.7 & $(0.2)$ \\
\hline 0.9502 & 12,4 & $(7,5$ & $11 \mathrm{c}$ & & 0.1 & & 49.7 & & & & 1.7 & & 138.0 & & 43895 & & 1.7 & $(0.1)$ \\
\hline 0.9708 & 4,8 & $(4,3)$ & 167 & (678) & 0.2 & $(0.5)$ & 50.4 & (12.8) & 28890 & (18120) & 1.7 & $(0.2)$ & 147.3 & (27.4) & 41197 & (17834) & 1.7 & $(0.1)$ \\
\hline 0.9915 & 8,4 & $(3,1)$ & 808 & (1760) & 0.3 & (0.6) & 45.0 & $(10.7)$ & 28374 & (15769) & 1.7 & $(0.2)$ & 145.4 & (14.1) & 39934 & (13401) & 1.7 & $(0.1)$ \\
\hline
\end{tabular}

Figure 5a presents the $\sigma$, Fig. 5b the GMD and the Fig. 5c the aerosol particle concentration. The most clear diurnal variation of the parameters can be seen in Fig. 5c. An increase of Aitken mode number concentration started around 6 a.m. $\left(7500 \mathrm{~cm}^{-3}\right.$, at 4 a.m.) and continued through to about
7.30 a.m. At the same time also the number concentration of nucleation mode increased. After this point the number concentration of both modes decreased until the concentration of Aitken mode increased again after 2 p.m. continuing to 6 p.m. reaching the concentration almost $60000 \mathrm{~cm}^{-3}$. The 


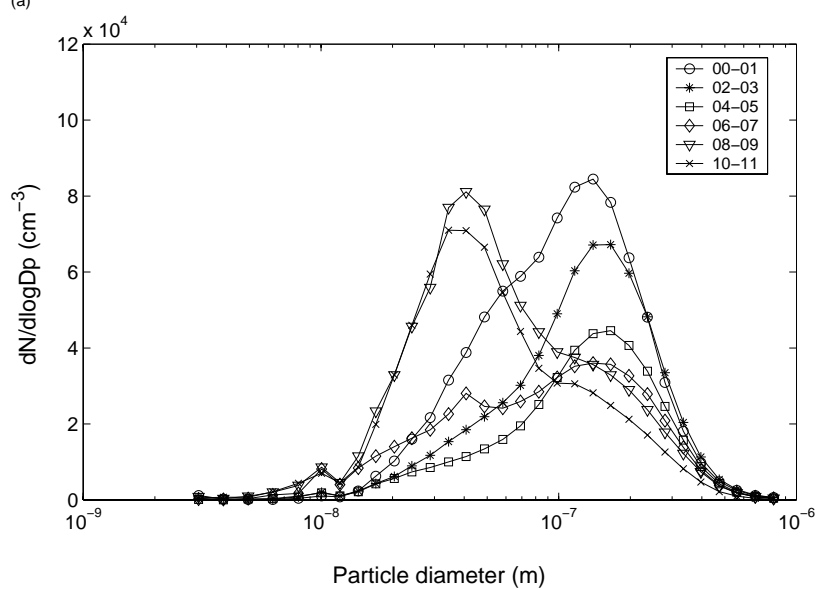

(b)

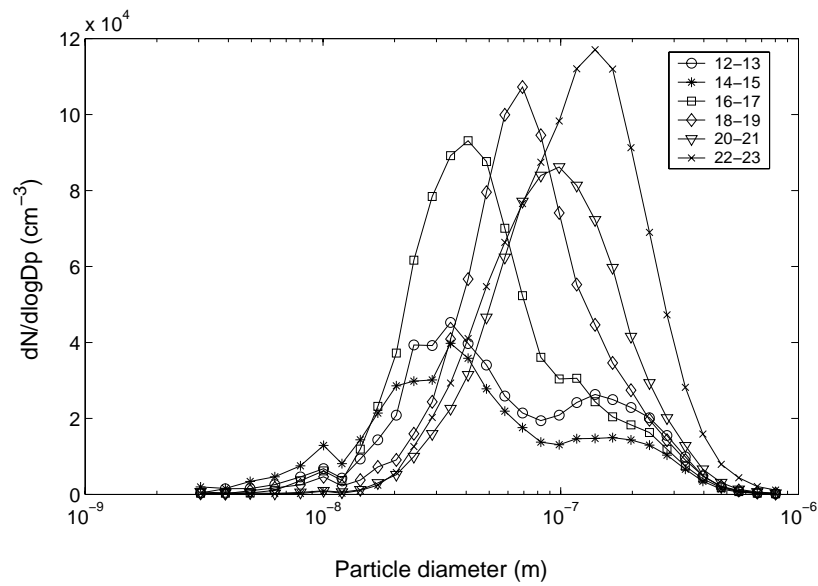

Fig. 4. Diurnal number size distributions (1 h mean) on 28 October (\#301) in New Delhi 2002. The Fig. 4a presents the size distributions before noon and the Fig. 4b size distributions after noon.

concentration of accumulation mode particles varied from 10000 (at 3 p.m.) to 40000 (at 0.15 a.m.) $\mathrm{cm}^{-3}$. A slight increase of accumulation mode particles was observed at mornings (7-8 a.m.) and more clear increase at evenings (610.30 p.m.).

There are several possible sources in New Delhi from where these particles are emitted to atmosphere. Firstly, the diurnal variations of the number concentration of Aitken mode particles at mornings and evenings indicate that these particles could be emitted from traffic. Ristovski et al. (1998) measured a typical number size distribution in the range of 15-750 nm (GMD close to $40 \mathrm{~nm}$ ) for the unleaded gasoline engine and for the CNG engine in the range of 15-200 nm (GMD of $59 \mathrm{~nm}$ ) (Ristovski et al., 2000). In New Delhi, CNG technology is widely used in buses, taxis and autorickshaws since the Supreme Court of India ordered on 28 July 1998, that entire city bus fleet to be steadily converted to single fuel mode on CNG by 31 March 2001 (Dursbeck et al., 2001).
Secondly, we might consider that the traffic was not the only source of these particles. The maximum GMD of Aitken mode particles was higher at evenings $(60 \mathrm{~nm}$ at 8 p.m.) than at mornings $(40 \mathrm{~nm}$ between $6-8$ a.m.). The GMD could increase at evenings as a result of burning biomass and refuse. This speculation is supported both by Pagels et al. (2003) and Sharma et al. (2003). Pagels et al. (2003) found unimodal number size distribution when combusting moist forest residue. The GMD of the number concentration varied between $85-110 \mathrm{~nm}$. Hence, it is possible that biomass burning increased the GMD at evenings in New Delhi. A very interesting result was found by Sharma et al. (2003). They analyzed chemical composition of organic species present in $\mathrm{PM}_{10}$ collected exactly at the same site as our DMPS measurements were conducted. Their study suggests that vehicular emissions and biomass and/or refuse burning are significant contributors to the organic fraction of $\mathrm{PM}_{10}$ in New Delhi's atmosphere.

Other possible sources beside vehicular emissions and/or refuse burning at evenings in New Delhi could be cooking. Few studies indicate that cooking with gas/LPG has a significant contribution to indoor number concentration levels (Dennekamp et al., 2001; Mönkkönen et al., 2004c). In New Delhi, LPG and burning biomass/other fossil fuels are the only form of cooking. Hence, the impact of cooking to the ambient air quality cannot be neglected while speculating the aerosol $\left(D_{p}<1000 \mathrm{~nm}\right)$ emissions in New Delhi.

\subsection{Observations of nucleation mode particle formation}

An example of particle nucleation event day, 29 October 2002 (\#302), is highlighted in Fig. 6, in which the evolution of the size distribution and total number concentration is shown as a function of time. New particles appeared at the lower end of the size spectrum at $3 \mathrm{~nm}$ around noon, and grow rapidly thereafter. These can be used to analyze useful features of the events, such as particle formation and growth rates.

Table 3 summarizes the observed nucleation events during the measuring campaign. The table presents the starting time of the event, event class, calculated particle formation rate for $3 \mathrm{~nm}$ particles (J3), growth rate (GR), condensation sink (CS) as well the concentration of condensable vapour $\mathrm{C}$ and their source rate Q (Kulmala et al., 2001) and concentrations of $\mathrm{SO}_{2}$ and $\mathrm{NO}_{2}$. CS and the concentration of $\mathrm{SO}_{2}$ and $\mathrm{NO}_{2}$ are given from the starting time of the event. Condensation sinks determines how rapidly molecules will condense on a preexisting aerosol. The events are classified in three different classes (Mäkelä et al., 2000b). During the measuring period we observed eight events.

Most of the events are classified as class 3 type events. This means that even though the event could be detected, the formation and growth of nucleation mode particles are disturbed by high aerosol background concentration. All events occurred usually at noon or afternoon when the solar 

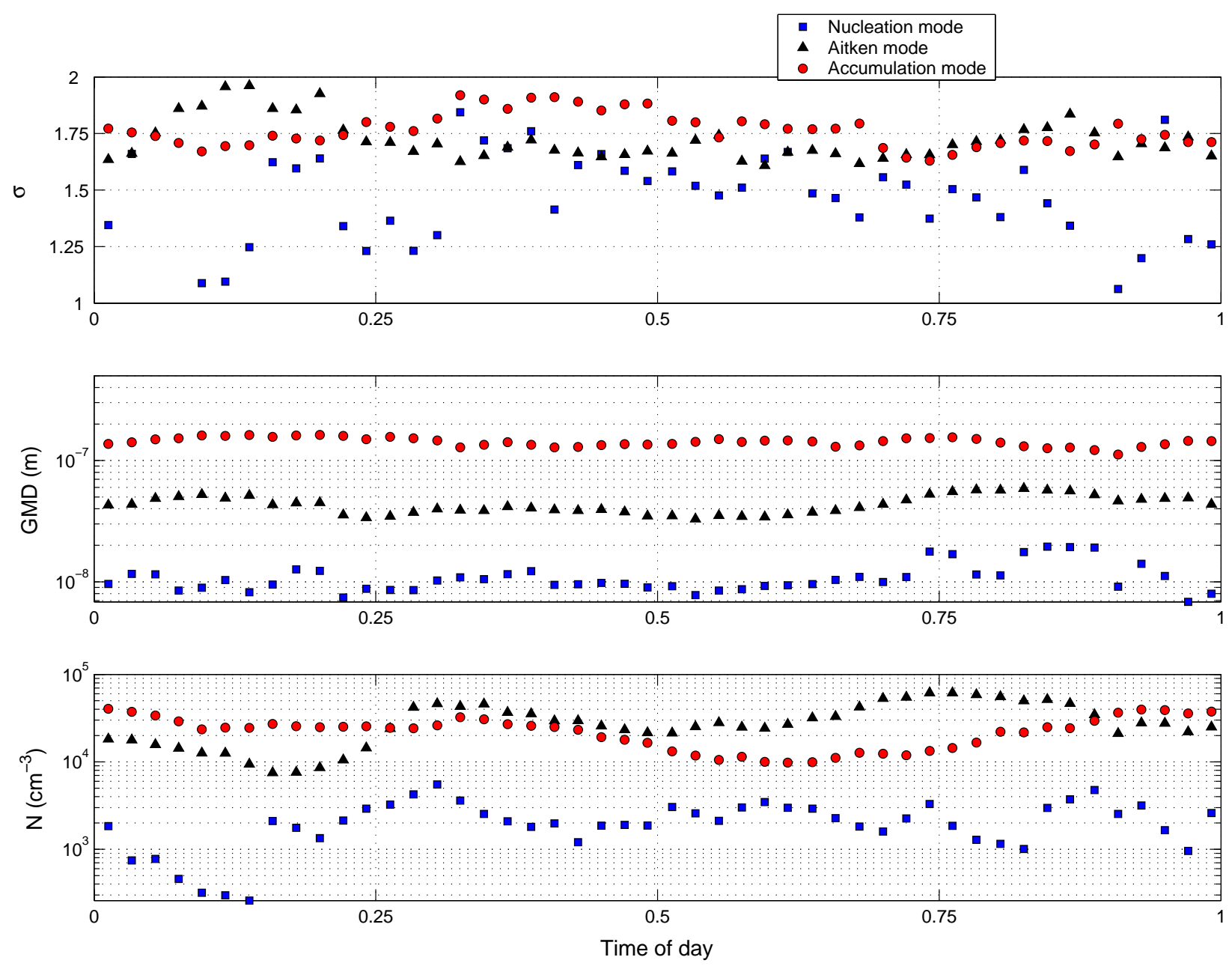

Fig. 5. Calculated geometric diurnal variations ( 30 min mean) of the modal parameters for each mode during the measuring campaign. Figure 5a represents the geometrical standard deviation $(\sigma)$, Fig. $5 \mathrm{~b}$ the geometric mean diameter (GMD) and the Fig. 5c the aerosol particle number concentration in mode.

Table 3. Observed nucleation events in New Delhi from 26 October to 9 November 2002.

\begin{tabular}{|c|c|c|c|c|c|c|c|c|c|c|}
\hline Day & Day of year & Starting time & Event class & $\mathrm{J} 3\left(\mathrm{~cm}^{-3} \mathrm{~s}^{-1}\right)$ & $\mathrm{GR}\left(\mathrm{nmh}^{-1}\right)$ & $\mathrm{CS}\left(\mathrm{s}^{-1}\right)$ (at start) & $\mathrm{C}\left(\mathrm{cm}^{-3}\right)$ & $\mathrm{Q}\left(\mathrm{s}^{-1} \mathrm{~cm}^{-3}\right)$ & $\mathrm{SO}_{2}\left(\mu \mathrm{gm}^{-3}\right)$ & $\mathrm{NO}_{2}\left(\mu \mathrm{gm}^{-3}\right)$ \\
\hline $28 \mathrm{Oct}$ & 301 & 14:00 & 2 & 4.6 & 18.1 & $5 e-2$ & $24.6 \mathrm{e} 7$ & $1.2 \mathrm{e} 7$ & 12.7 & 72.1 \\
\hline $29 \mathrm{Oct}$ & 302 & $12: 00$ & 2 & 8.3 & 11.6 & $6 e-2$ & $15.8 \mathrm{e} 7$ & $0.9 \mathrm{e} 7$ & 9.7 & 38.9 \\
\hline $5 \mathrm{Nov}$ & 309 & $11: 00$ & 3 & 5.6 & 16.0 & $5 e-2$ & $21.8 \mathrm{e} 7$ & $1.1 \mathrm{e} 7$ & 11.4 & 49.7 \\
\hline $7 \mathrm{Nov}$ & 311 & 12:00 & 3 & 12.5 & 14.9 & $5 e-2$ & $20.3 \mathrm{e} 7$ & $1.0 \mathrm{e} 7$ & 8.0 & 83.0 \\
\hline $8 \mathrm{Nov}$ & 312 & $15: 00$ & 3 & 4.9 & 13.8 & $7 e-2$ & $18.8 \mathrm{e} 7$ & $1.3 \mathrm{e} 7$ & 14.6 & 64.2 \\
\hline
\end{tabular}

radiation is most intensive. Similar event starting times were also observed in Atlanta (Woo et al., 2001) and daytime nucleation events were also reported in Mexico City (Dunn et al., 2004).
Unfortunately clear results on the connection between different trace gases and new particle formation cannot be achieved from our data set. The $\mathrm{SO}_{2}$ and $\mathrm{NO}_{2}$ concentrations were relatively high during the whole campaign. Since the time resolution to measure these gases was $4 \mathrm{~h}$, conclusions of their role in formation and growth of nucleation mode 

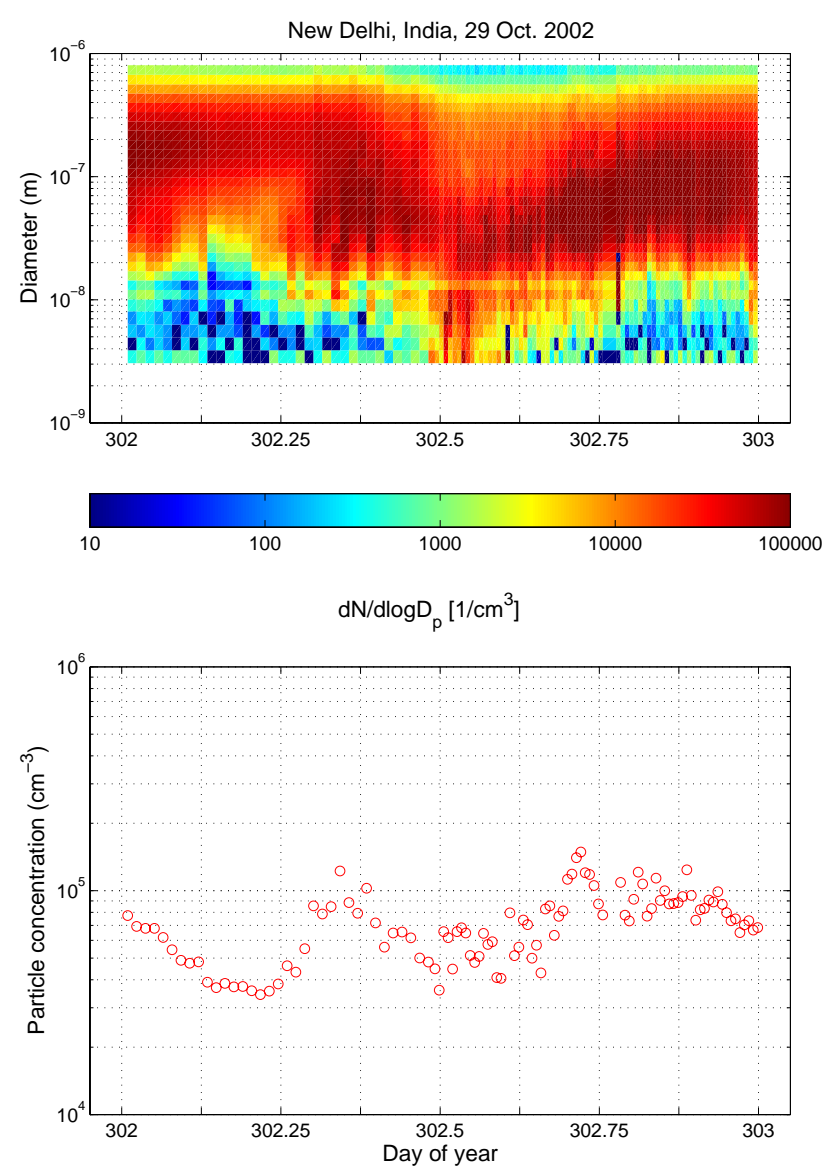

Fig. 6. Evolution of particle number distribution and total number concentration as a function of time for 29 October 2002.

particles in New Delhi cannot be made. However, the sulphuric acid might play a significant role in New Delhi as it plays important role in Mexico City (Dunn et al., 2004).

Figure 7 presents an example of the calculated condensation sink and aerosol surface area values from 27 to 29 October (\#300-302). It is important to note that at the event starting time for both the condensation sink and aerosol surface area was in its minimum initiating a new particle formation event to occur. Similar results were also obtained from Mexico City. The analysis by Dunn et al. (2004) suggested that particle formation events occur in New Mexico when $\mathrm{PM}_{10}$ mass concentration were at a significantly lower level than their averages hence decreasing condensational surface area.

The formation rate varied from 3.3 to $13.9 \mathrm{~cm}^{-3} \mathrm{~s}^{-1}$ which were similar magnitude with formation rates observed in Atlanta (McMurry et al., 2005 ${ }^{1}$ ). The growth rates varied 11.6 to $18.1 \mathrm{nmh}^{-1}$, which were slightly higher that rates $(0.5$ to $9 \mathrm{nmh}^{-1}$ ) reported for Mexico City (Dunn et al., 2004). The $\mathrm{Q}$ value is significantly higher (about 100 times) than in the rural forest in Hyytiälä, Finland. Also the growth rate and

\footnotetext{
${ }^{1}$ McMurry, P. H., Woo, K. S., and Shi, Q.: in preparation, 2005.
}

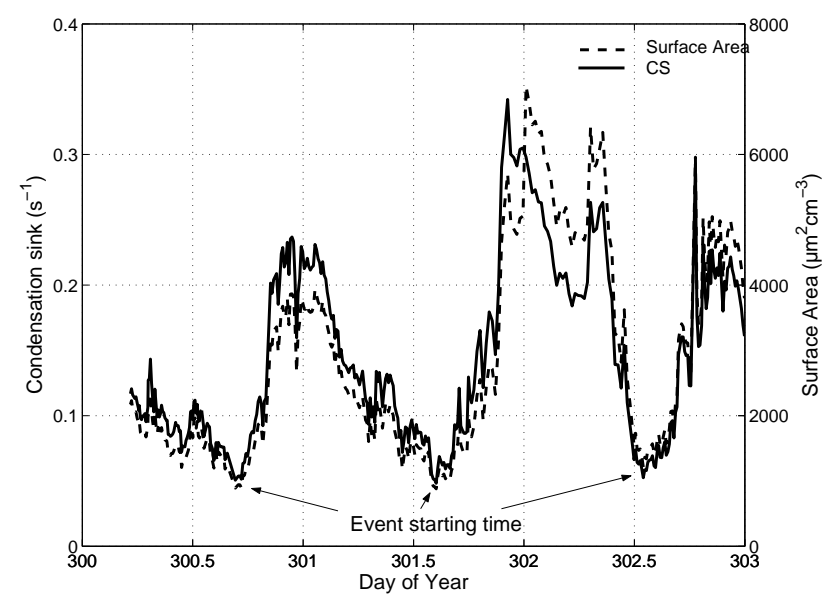

Fig. 7. Condensation sinks and aerosol surface areas as a function of time from 27 to 29 October 2002 (\#300-302).

$\mathrm{C}$ are around 5 times higher and CS around 20 times higher than in Hyytiälä (Kulmala et al., 2001; Kulmala et al., 2004). This shows that in polluted urban environments high source rates of condensable vapours are necessary so that the condensational growth wins the aerosol dynamical competition with coagulation sink.

\section{Conclusions}

In this study we have for the first time presented the diurnal variation of the number size distribution (3-800 nm) and the modal parameters of urban background aerosols in a highly polluted Asian mega city.

We have also shown that nucleation events are possible in highly polluted urban environment. Observed formation events were disturbed by high pre-existing aerosol population, and hence, as clear nucleation events than observed in rural background areas (e.g. Hyytiälä, Finland) could not be detected. The observed formation rate (J3) and the growth rate showed rapid growth and high formation rate, which seems to be typical in urban areas (Kulmala et al., 2004). In the case of every observed event, the condensation sink was at minimum during event starting time. The source of condensable vapour molecules is seen to be 100 times higher than corresponding source in rural area (Kulmala et al., 2001). This shows that the formation of new secondary aerosol particles in polluted urban environment is possible, but requires high vapour sources in order to be able to overcome high coagulation sink (Kulmala et al., 2004a).

The analysis of diurnal modal parameters revealed that there is also another source in the evenings, which beside the traffic is frequently repeated every day. Based on the diurnal variation of aerosol number size distribution and modal parameters presented in this study and the study conducted by Sharma et al. (2003), vehicular emissions together with biomass and/or refuse burning might have 
significant contribution to New Delhi's atmosphere. Also the impact of cooking and new particle formation cannot be neglected.

Edited by: U. Lohmann

\section{References}

Aalto, P., Hämeri, K., Becker, E., Weber, R., Salm, J., Mäkelä, J. M., Hoell, C., O’Dowd, C. D., Karlsson, H., Hansson, H.- C., Väkevä, M., Koponen, I. K., Buzorius, G., and Kulmala, M.: Physical characterization of aerosol particles during nucleation events, Tellus B, 53, 344-358, 2001.

Alam, A., Shi Ping, J., and Harrison, R.: Observations of new particle formation in urban air, J. Geophys. Res., 108 (D3), doi:10.1029/2001/JD001417, 2003.

Baumgardner, D., Raga, G. B., Kok, G., Ogren, J., Rosas, I., Baez, A., and Novakov, T.: On the evolution of aerosol properties at a mountain site above Mexico City, J. Geophys. Res., 105 (D17), 22 243-22 253, 2000.

Baldasano, J. M., Valera, E., and Jiménez, P.: Air quality data from large cities, The Science of the Total Environment, 307, 1-3, 141-165, 2003.

Dennekamp, M., Howarth, S., Dick, C. A. J., Cherrie, J. W., Donaldson, K., and Seaton, A.: Ultrafine particles and nitrogen oxides generated by gas and electric cooking, Occupational Environmental Medicine, 58, 511-516, 2001.

de Reus, M., Krejci, R., Williams, J., Fischer, H., Scheele, R., and Ström, J.: Vertical and horizontal distributions of the aerosol number concentration and size distribution over the northern Indian Ocean, J. Geophys. Res., 106 (D22), 28 629-28 641, 2001.

Dunn, M. J., Jimenez, J.-L., Baumgardner, D., Castro, T., McMurry, P. H., and Smith, J. N.: Measurements of Mexico City nanoparticle size distributions: Observations of new particle formation and growth, J. Geophys. Lett., 31, LI10102, doi:10.1029/2004GL019483, 2004.

Dursbeck, F., Erlandsson L., and Weawer, C.: Status of implementation of CNG as a fuel for urban buses in Delhi, Centre for Science and Environment, New Delhi, http://www.cleanairnet.org/ caiasia/1412/propertyvalue-14418.html, 2001.

Faiz, A. and Sturm, P. J.: New Directions: Air pollution and road traffic in developing countries, Atmos. Environ., 34, 27, 47454746, 2000.

Goyal P. and Krishna T. V. B. P. S. R.: Various methods of emission estimation of vehicular traffic in Delhi, Transps. Res.-D, 31, 5, 309-317, 1998.

Hämeri, K., Kulmala, M., Aalto, P., Leszczynski, K., Visuri, R., and Hämekoski, K.: The investigations of aerosol particle formation in urban background area in Helsinki, Atmos. Res., 41, 281-298, 1996.

Jayaratne, E. R. and Verma, T. S.: The impact of biomass burning on the environmental aerosol concentration in Gaborone, Botswana, Atmos. Environ., 35, 10, 1821-1828, 2001.

Jokinen, V. and Mäkelä, J. M.: Closed loop arrangement with critical orifice for DMA sheath/excess flow system, J. Aero. Sci., 28, 643-648, 1997.

Kamra, A. K., Murugavel, P., and Pawar, S. D.: Measured size distribution of aerosols over Indian Ocean during INDOEX, J. Geo- phys. Res., 108 (D3), 8000, doi:10.1029/2002JD002200, 2003.

Kittelson, D. B.: Engines and Nanoparticles: A Review, J. Aero. Sci., 29 (5/6), 575-588, 1998.

Krishnamoorthy, K. and Saha, A.: Aerosol study during INDOEX: observation of enhanced aerosol activity over the Mid Arabian Sea during the northern winter, J. Atmos. Sol.-Terr. Phys., 62, 65-72, 2000.

Krishnamoorthy, K., Satheesh, S. K., and Krishamurthy, B. V.: Investigation of marine aerosols over the tropical Indian Ocean, J. Geophys. Res., 102, 18 827-18 842, 1997.

Kulmala, M., Maso, Dal M., Mäkelä, J. M., Pirjola, L., Väkevä, M., Aalto, P., Miikkulainen, P., Hämeri, K., and O’Dowd, C. D.: On the formation, growth and composition of nucleation mode particles, Tellus, 53B, 479-490, 2001.

Kulmala, M., Petäjä, T., Mönkkönen, P., Koponen, I. K., Dal Maso, M., Aalto, P. P., Lehtinen, K. E. J., and Kerminen, V.-M.: On the growth of nucleation mode particles: source rates of condensable vapor in polluted and clean environments, Atmos. Chem. Phys. Discuss., 4, 6943-6966, 2004a,

SRef-ID: 1680-7375/acpd/2004-4-6943.

Kulmala, M., Vehkamäki, H., Petäjä,T., Maso, Dal M., Lauri, A., Kerminen, V.-M., Birmili, W., and McMurry, P. H.: Formation and growth rates of ultrafine atmospheric particles: a review of observations, J. Aero. Sci., 35, 143-176, 2004 b.

Longley, I. D., Gallagher, M. W., Dorsey, J. R., Flynn, M., Allan, J. D., Alfarra, M. R., and Inglis, D.: A case study of aerosol $\left(4.6 \mathrm{~nm}<D_{p}<10 \mathrm{~nm}\right)$ number and mass size distribution measurements in a busy street canyon in Manchester, UK, Atmos. Environ., 37, 2, 1563-1571, 2003.

Mitra, A. P. and Sharma, C.: Indian aerosols: present status, Chemosphere, 49, 1175-1190, 2002.

Murugavel, P. and Kamra, A. K.: Changes in the concentration and size distribution of the sub-micron particles associated with the sea- and land-breezes at a coastal station, Current Science (Indian Academy of Science), 76, 7, 994-997, 1999.

Mönkkönen, P., Uma, R., Srinivasan, D., Koponen, I. K., Lehtinen, K. E. J., Hämeri, K., Suresh, R., Sharma, V. P., and Kulmala, M.: Relationship and variations of aerosol number and PM10 mass concentrations in a highly polluted urban environment, Atmos. Environ., 38, 425-433, 2004a.

Mönkkönen, P., Koponen, I. K., Lehtinen, K. E. J, Uma, R., Srinivasan, D., Hämeri, K., and Kulmala, M.: Death of nucleation and Aitken mode particles: Observations at extreme atmospheric conditions and their theoretical explanation, J. Aero. Sci., 35, 781-787, 2004b.

Mönkkönen, P., Pai, P., Maynard, A., Lehtinen, K. E. J., Hämeri, K., Andresen, P., Ramachandran, G., Prasad, B., and Kulmala, M.: Fine particle number and mass concentration measurements in urban Indian household, The Science of the Total Environment, in press, 2005.

Mäkelä, J. M., Koponen, I. K., Aalto, P., and Kulmala, M.: Oneyear data of submicron size modes of tropospheric background aerosol in southern Finland, J. Aero. Sci., 31, 595-611, 2000a.

Mäkelä, J. M., Dal Maso, M., Pirjola, L., Keronen, P., Laakso, L., Kulmala, M., and Laaksonen, A.: Characteristics of the atmospheric particle formation events observed at a boreal forest site in southern Finland, Bor. Environ. Sci., 5, 299-313, 2000b.

Pagels, J., Strand, M., Rissler, J., Szpila, A., Gudmundsson, A., Bohgard, M., Lillieblad, L., Sanati, M., and Swietlicki, E.: Char- 
acteristics of aerosol particles formed during grate combustion of moist forest residue, J. Aero. Sci., 34, 1043-1059, 2003.

Pitz, M., Kreying, W. G., Hölscher, B., Cyrys, J., Wichmann, H. E., and Heinrich, J.: Change of the ambient particle size distribution in East Germany between 1993 and 1999, Atmos. Environ., 35, 4357-4366, 2001.

Quant, F. R., Caldow, R., Sem, G. J., and Addison, T. J.: Performance of condensation particle counters with three continuousflow designs, J. Aero. Sci., 23, 1, 405-408, 1992.

Rao, P. S. P., Momin, A. G., Safai, P. D., Ali, K., Naik, M. S., and Pillai, A. G.: Studies of trace gases and Aitken Nuclei at inland and coastal stations - A part of INDOEX proramme, Current Science (Indian Academy of Science), 76, 7, 981-984, 1999.

Reddy, M. S. and Venkataraman, C.: Inventory of aerosol and sulphur dioxide emissions from India: I - Fossil fuel combustion, Atmos. Environ., 36, 677-697, 2002a.

Reddy, M. S. and Venkataraman, C.: Inventory of aerosol and sulphur dioxide emissions from India: Part II - Biomass combustion, Atmos. Environ., 36, 699-712, 2002b.

Ristovski, Z. D., Morawska, L., Hitchins, J., Thomas, S., Greenaway, C., and Gilbert, D.: Particle emissions from compressed natural gas engines, J. Aero. Sci., 31, 403-413, 2000.

Ristovski, Z. D., Morawska, L., Bofinger, N., and Hitchins, J.: Submicrometer and supermicrometer particulate emission from spark ignition vehicles, Environ. Sci. Technol., 32, 3845-3852, 1998.

Sharma, D. N., Sawant, A. A, Uma, R., and Cokker III, D. R.: Preliminary chemical characterization of particle-phase organic compounds in New Delhi, Atmos. Environ., 37, 4317-4323, 2003.

Shi, J. P., Evans, D. E., Khan, A. A., and Harrison, R. M.: Sources and concentration of nanoparticles $(<10 \mathrm{~nm}$ in diameter $)$ in the urban atmosphere, Atmos. Environ., 35, 1193-1202, 2001.
Shi, J. P., Khan, A. A., and Harrison, R. M.: Measurements of ultrafine particle concentration and size distribution in the urban atmosphere, The Science of the Total Environment, 235, 51-64, 1999.

Shi, J. P., Sakurai, H., and McMurry, P. H.: Measurements of St. Louis aerosol size distributions: Observations of particle events, Paper presented at 21st Annual AAAR Conference, October 711, Charlotte, North Carolina, 2002.

Stainer, C. O, Khlystov, A. Y., Wittig, B., Pandis, S. N., Zhou, Y., Bein, K., Wexler, A. S., Misra, C., and Sioutas, C.: Investigation of nucleation burst during Pittsburg Air Quality Study, Paper presented at 21st Annual AAAR Conference, October 7-11, Charlotte, North Carolina, 2002.

Stolzenburg, M. R. and McMurry, P. H.: An ultrafine aerosol condensation nucleus counter, Aero. Sci. Technol., 14, 48-65, 1991.

Wehner, B. and Wiedensohler, A.: Long term measurements of submicrometer urban aerosols: statistical analysis for correlations with meteorological conditions and trace gases, Atmos. Chem. Phys., 3, 867-879, 2003,

SRef-ID: 1680-7324/acp/2003-3-867.

Williams, P. I., Choularton, T. W., Gallagher, M., Coe, W. H., and Bower, K. N.: Results of monitoring ultra-fine, fine and accumulation mode particles above an urban canyon within the city of Manchester, J. Aero. Sci., 29, S593-S594, 1998.

Winklmayr, W., Reischl, G. P., Lindner, A. O., and Berner, A.: A new electromobility spectrometer for the measurement of aerosol size distributions in the size range from 1 to $1000 \mathrm{~nm}$, J. Aero. Sci., 22, 289-296, 1991.

Woo, K. S., Chen, D. R., Pui, D. Y. H., and McMurry, P. H.: Measurements of Atlanta Aerosol Size Distributions: Observations of Ultrafine Particle Events, Aero. Sci. Technol. 34, 75-87, 2001. 